\title{
Obstetrics and Gynaecology as a Future Career for Medical Graduates in Oman \\ Factors that attract and discourage graduates
}

Asma Al Salehi, ${ }^{1}$ Tamima Al Dughaishi, ${ }^{2}$ Gauhar Rizvi, ${ }^{3}$ "Vaidyanathan Gowri ${ }^{4}$

$$
\begin{aligned}
& \text { تخصص أمراض النساء والولادة كمهنة طبية مستقبلية للأطباء الخريجين في عمان } \\
& \text { العوامل الجاذبة والعوامل المثبطة للخريجين }
\end{aligned}
$$

$$
\text { أسماء الصالحية، تميمة الدغيشية، جوهر رزفي، جاوري فيدياناثان }
$$

ABSTRACT: Objectives: Obstetrics and gynaecology (OBGYN) is a major speciality in the medical field that is often demanding yet rewarding; however, OBGYN receives the least number of applicants in Oman. This study aimed to determine the factors that influence graduates in choosing OBGYN as their speciality. Methods: This cross-sectional questionnaire-based study was conducted from February to March 2017 at Sultan Qaboos University Hospital, Royal Hospital, Khoula Hospital and Al Nahdha Hospital, Muscat, Oman. The questionnaire was distributed to 150 Omani medical graduates (interns and post-intern doctors). Results: A total of 145 Omani graduates took part in the study (response rate: 96.7\%) and the participants' average age was 26 years. Family medicine ranked as the first choice followed by paediatrics and emergency medicine. OBGYN was the first choice for eight female graduates. The top factors attracting male graduates to the OBGYN speciality were its surgical opportunities (80.6\%), intellectual content (77.4\%), faculty interactions and the opportunity to care for a healthy population ( $54.8 \%$ each); however, the top factors attracting females were the intellectual content (88.6\%), patients' desire for female physicians $(85.1 \%)$, the opportunity to care for a healthy population $(76.3 \%)$ and cultural expectations $(69.5 \%)$. The most discouraging factors for male graduates were cultural expectations (100\%), the patients' desire for a female physician (93.5\%) and the level of stress $(71 \%)$, while the discouraging factors for female graduates were the level of stress $(82.5 \%)$, time demands (78.1\%), night duties and the length of the residency (71.9\% each). Conclusion: Most of the factors that discourage female graduates from choosing OBGYN are to some extent modifiable. These changes should be considered to encourage the selection of OBGYN as a career by medical students.

Keywords: Career Choice; Obstetrics and Gynecology Department, Hospital; Internship and Residency; Medical Student; Oman.

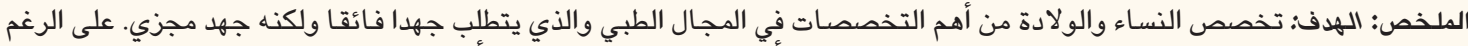

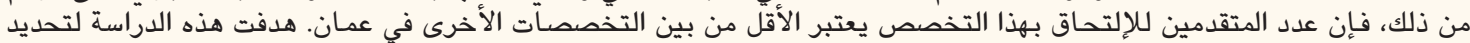

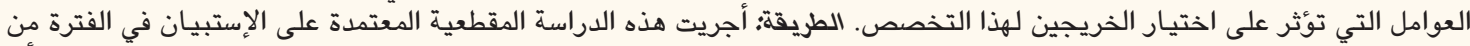

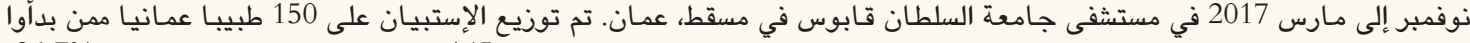

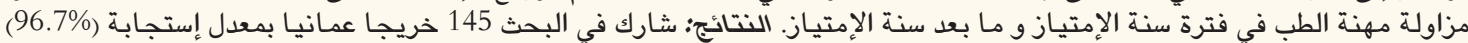

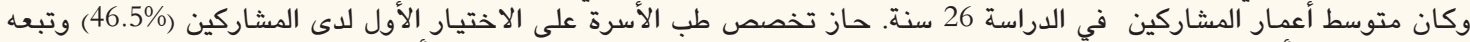

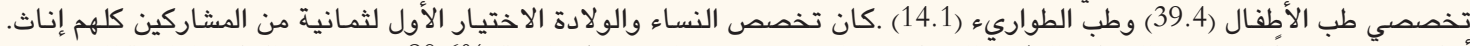

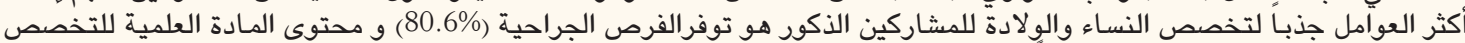

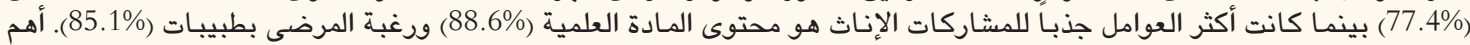

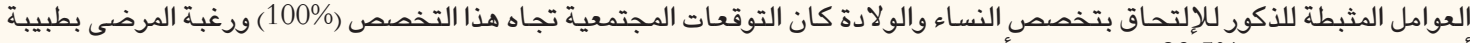

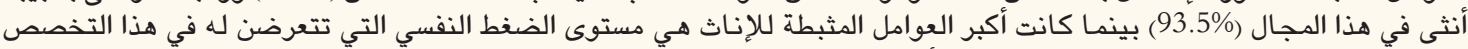

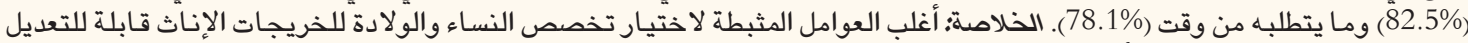
إلى حد ما. هذه التعديلات يجب أن تؤخذ في الإعتبار وذلك لتحفيز طالبات الطب لاختيار تخصص الخص النساء و الولادة كمهنة طبية لمزاولتها

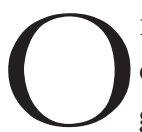
BSTETRICS AND GYNAECOLOGY (OBGYN) IS one of the major specialities that medical graduates can choose as a career. However, in Oman, the number of graduates applying for residency in this speciality is low. Obstetrics is both a gratifying and demanding practice. ${ }^{1}$ Abu-Rafea et al's study, cond- ucted in Saudi Arabia, showed that the rotation of students through OBGYN was the most influential factor in choosing this speciality as a career, attracting $81.3 \%$ of the students, followed by faculty interactions (71.9\%). The factors that did not have a significant impact on the career decision included lifestyle and income 
prospects, mostly dealing with healthy patients, stress levels and the time demands of the speciality. ${ }^{2}$

Scott et al's study was conducted in Canada and found that students' ultimate decision to choose OBGYN as their career when they started medical school depended on three elements-selecting it as their first choice at this early stage, being female and wanting a narrow scope of practice. ${ }^{3}$

In a study conducted in the USA, Chang et al. reported that the interest in an OBGYN career was stimulated by residents who behaved professionally and also by the students feeling that they were part of the team, including being asked to perform some tasks in the operating room. ${ }^{4}$ They found that males were more interested in this career if they were included as a functioning part of the team.

In contrast to Chang et al.s study, Fogarty et al. found that female students were more interested in this speciality than male students. Furthermore, this study reported that students' decision were influenced by several factors-including the OBGYN staff, continuity of patient care, primary care opportunities, surgical opportunities and dealing with a healthy patient population. ${ }^{5}$ In addition, malpractice concerns did not negatively influence their choice. ${ }^{5}$

The number of births in Oman continued to rise between 2011 and 2016 with 18,987 live births and a change rate of $30 \% .{ }^{6}$ Consequently, this increase in births requires more specialists to be trained and employed in OBGYN. At Sultan Qaboos University Hospital (SQUH), Muscat, Oman, the current intake is approximately six residents per year; however, this figure is variable as many of the residents do not take OBGYN as their first choice and there is a high dropout rate (approximately 15\%; unpublished data). A study to determine the factors that attract Omani medical graduates towards OBGYN as a future career or discourage them from it is required as the need for specialists in this area is continually increasing. This study aimed to determine the factors that attract and discourage the choice of OBGYN as a future career for Omani medical graduates and suggests solutions for the most common discouraging factors.

\section{Methods}

This observational cross-sectional study was conducted from February to March 2017 at SQUH. Questionnaires were distributed to a convenient sample of 150 Omani medical graduates - both interns and post-intern doctors-of which a total of 145 (response rate: 96.7\%) completed the questionnaire. The sample size was 150 as only the interns rotating in Muscat were included as other interns were posted elsewhere at the time the study was conducted. It was not possible to include only final year students as most students do clerkships in the final year and the sample size would have been too small. Increasing the duration of the study would not have increased the sample size. The survey evaluated age, gender, place of origin, marital status, the medical school they graduated from-Sultan Qaboos University (SQU), Oman Medical College (OMC) or medical schools abroad-their future residency choices and the reasons for these choices.

Those who did not respond to the question; "Do you have an interest in specialising in OBGYN as a future career?", were classified as 'unsure'.

This research was approved by the Medical Research Ethical Committee (MREC \#1428). Verbal consent was given by the participants who completed the survey.

\section{Results}

A total of 114 (78.6\%) female and 31 (21.4\%) male participants completed the questionnaire; the participants' average age was 26 years (range: $23-29$ years). The majority of the participants graduated from SQU (51\%), followed by OMC (40\%) and medical schools from abroad (9\%). According to the graduates' responses, family medicine ranked first as a preferred future career (46.5\%), followed by paediatrics (39.4\%) and emergency medicine (14.1\%) [Figure 1]. Male graduates generally preferred paediatrics and emergency medicine while female graduates preferred family medicine (26.3\%), paediatrics (20\%) and OBGYN (7\%).

Of all the Omani graduates, only 20 expressed an interest in the OBGYN speciality while 108 showed no interest and 17 were unsure. Only one male graduate expressed an interest in OBGYN. Out of the female graduates, 19 expressed interest in the OBGYN speciality, 82 showed no interest and 13 were unsure. Of the eight graduates who chose OBGYN as their first choice speciality, two graduated from abroad, four were SQU graduates and two were OMC graduates.

The main factors attracting male graduates to the OBGYN speciality were surgical opportunities (80.6\%), intellectual content of OBGYN (77.4\%), taking care of a healthy population $(54.8 \%)$ and faculty interaction (54.8\%). On the other hand, cultural expectations (100\%), patients' desire for a female physician (93.5\%), level of stress (71\%) and spouse or family opinion (64.5\%) were the most discouraged factors [Table 1].

The main factors attracting female graduates to the OBGYN speciality were its intellectual content (88.6\%), patients' desire for a female physician (85.1\%), taking care of a healthy population (76.3\%) and cultural expectations (69.3\%). Level of stress (82.5\%), time demands (78.1\%), night duties (71.9\%) and the length of residency (71.9\%) were the most discouraging factors in choosing 


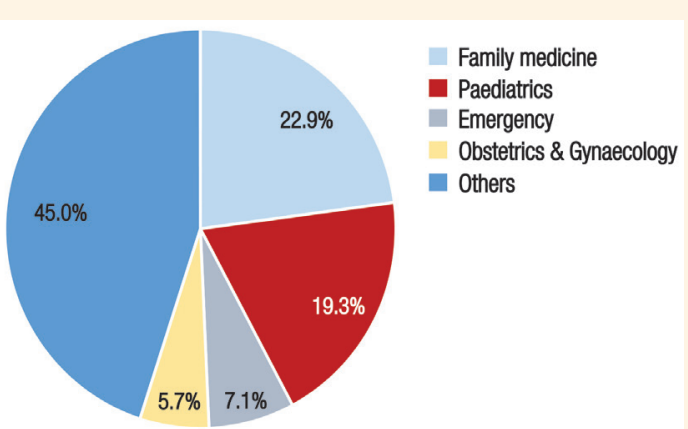

Figure 1: Preferred future speciality of Omani medical graduates $(\mathrm{N}=145)$.

Table 1: Attracting and discouraging factors of the obstetrics and gynaecology speciality for male Omani medical graduates $(\mathrm{N}=31)$

\begin{tabular}{|c|c|c|c|}
\hline \multirow[t]{2}{*}{ Factor } & \multicolumn{3}{|c|}{ n (\%) } \\
\hline & Attracted & Discouraged & Neutral \\
\hline $\begin{array}{l}\text { Rotation through OB- } \\
\text { GYN during medical } \\
\text { school }\end{array}$ & $16(51.6)$ & $11(35.5)$ & $4(12.9)$ \\
\hline $\begin{array}{l}\text { Presence of a role model } \\
\text { in OBGYN speciality }\end{array}$ & $13(41.9)$ & $8(25.8)$ & $10(32.3)$ \\
\hline Faculty interaction & $17(54.8)$ & $12(38.7)$ & $2(6.5)$ \\
\hline Faculty encouragement & $16(51.6)$ & $10(32.3)$ & $5(16.1)$ \\
\hline $\begin{array}{l}\text { Previous interaction } \\
\text { with OBGYN residents }\end{array}$ & $12(38.7)$ & $7(22.6)$ & $12(38.7)$ \\
\hline $\begin{array}{l}\text { Taking care of a healthy } \\
\text { population }\end{array}$ & $17(54.8)$ & $6(19.4)$ & $8(25.8)$ \\
\hline $\begin{array}{l}\text { Patients' desire for a } \\
\text { female physician }\end{array}$ & $0(0)$ & $29(93.5)$ & $2(6.5)$ \\
\hline Cultural expectations & $0(0)$ & $31(100)$ & $0(0)$ \\
\hline Surgical opportunities & 25 (80.6) & $5(16.1)$ & $1(3.2)$ \\
\hline Hands-on procedures & $16(51.6)$ & $13(41.9)$ & $2(6.5)$ \\
\hline $\begin{array}{l}\text { Intellectual content of } \\
\text { OBGYN }\end{array}$ & $24(77.4)$ & $5(16.1)$ & $2(6.5)$ \\
\hline Length of residency & $9(29)$ & $14(45.2)$ & $8(25.8)$ \\
\hline Time demands & $6(19.4)$ & $11(35.5)$ & $14(45.2)$ \\
\hline Level of stress & $3(9.7)$ & $22(71)$ & $6(19.4)$ \\
\hline Night duties & $3(9.7)$ & $16(51.6)$ & $12(38.7)$ \\
\hline $\begin{array}{l}\text { Income prospects/ } \\
\text { financial opportunities }\end{array}$ & $12(38.7)$ & $11(35.5)$ & $8(25.8)$ \\
\hline Spouse/family opinion & $2(6.5)$ & $20(64.5)$ & $9(29)$ \\
\hline $\begin{array}{l}\text { Affect family life/ } \\
\text { family considerations }\end{array}$ & $0(0)$ & $19(61.3)$ & $12(38.7)$ \\
\hline
\end{tabular}

OBGYN as a future career for female graduates [Table 2]. Factors influencing female graduates' choice have been separated according to the institution of graduation in Table 3.
Table 2: Attracting and discouraging factors of the obstetrics and gynaecology speciality for female Omani medical graduates $(\mathrm{N}=114)$

\begin{tabular}{|c|c|c|c|}
\hline \multirow[t]{2}{*}{ Factor } & \multicolumn{3}{|c|}{ n (\%) } \\
\hline & Attracted & Discouraged & Neutral \\
\hline $\begin{array}{l}\text { Rotation through OB- } \\
\text { GYN during medical } \\
\text { school }\end{array}$ & $78(68.4)$ & $31(27.2)$ & $5(4.4)$ \\
\hline $\begin{array}{l}\text { Presence of a role model } \\
\text { in OBGYN speciality } \\
\text { school }\end{array}$ & $67(58.8)$ & $14(12.3)$ & $33(28.9)$ \\
\hline Faculty interaction & $43(37.7)$ & $60(52.6)$ & $11(9.6)$ \\
\hline Faculty encouragement & $64(56.1)$ & $25(21.9)$ & $25(21.9)$ \\
\hline $\begin{array}{l}\text { Previous interaction } \\
\text { with OBGYN residents }\end{array}$ & $55(48.2)$ & $13(11.4)$ & $46(40.4)$ \\
\hline $\begin{array}{l}\text { Taking care of a healthy } \\
\text { population }\end{array}$ & $87(76.3)$ & $10(8.8)$ & $17(14.9)$ \\
\hline $\begin{array}{l}\text { Patients' desire for a } \\
\text { female physician }\end{array}$ & $97(85.1)$ & $4(3.5)$ & $13(11.4)$ \\
\hline Cultural expectations & $79(69.3)$ & $5(4.4)$ & $30(26.3)$ \\
\hline Surgical opportunities & $61(53.5)$ & $46(40.4)$ & $7(6.1)$ \\
\hline Hands-on procedures & $78(68)$ & $30(26.3)$ & $6(5.3)$ \\
\hline $\begin{array}{l}\text { Intellectual content of } \\
\text { OBGYN }\end{array}$ & $101(88.6)$ & $8(7)$ & $5(4.4)$ \\
\hline Length of residency & $15(13.2)$ & $82(71.9)$ & $17(14.9)$ \\
\hline Time demands & $12(10.5)$ & $89(78.1)$ & $13(11.4)$ \\
\hline Level of stress & $6(5.3)$ & $94(82.5)$ & $14(12.3)$ \\
\hline Night duties & $5(4.4)$ & $82(71.9)$ & $27(23.7)$ \\
\hline $\begin{array}{l}\text { Income prospects/ } \\
\text { financial opportunities }\end{array}$ & $58(50.9)$ & $15(13.2)$ & $41(36)$ \\
\hline Spouse/family opinion & $49(43)$ & $38(33.3)$ & $27(23.7)$ \\
\hline $\begin{array}{l}\text { Affect family life/ } \\
\text { family considerations }\end{array}$ & $5(4.4)$ & $76(66.7)$ & $33(28.9)$ \\
\hline$C Y N=$ a ctotrice and & ecology. & & \\
\hline Discussion & & & \\
\hline
\end{tabular}

In this study 20 participants (19 female and one male) expressed an interest in the OBGYN speciality, although not as their first career choice. Some of the factors that attracted both genders to OBGYN were the intellectual content, dealing with a healthy population and faculty interaction; male graduates were also attracted by the surgical opportunities. Some of these factors are similar to the findings in the survey by Fogarty et al. ${ }^{5}$

Work hours and liability concerns discouraged residents from choosing OBGYN in a study by Ogburn et al.; the current study also reflects these findings. Actively involving medical students in the speciality during clinical year rotations and internship training will help increase the number of Omani female medical graduates that join the OBGYN speciality. ${ }^{4}$ No parti- 
Table 3: Attracting and discouraging factors of the obstetrics and gynaecology speciality for female graduates according to institution of graduation $(\mathrm{N}=114)$

\begin{tabular}{|c|c|c|c|c|c|c|c|c|c|}
\hline \multirow[t]{2}{*}{ Factor } & \multicolumn{9}{|c|}{ n (\%) } \\
\hline & $\begin{array}{c}\text { SQU } \\
(n=49)\end{array}$ & $\begin{array}{c}\text { OMC } \\
(\mathrm{n}=55)\end{array}$ & $\begin{array}{c}\text { Abroad } \\
\text { graduates } \\
(\mathbf{n}=10)\end{array}$ & $\begin{array}{c}\text { SQU } \\
(n=49)\end{array}$ & $\begin{array}{c}\text { OMC } \\
(\mathrm{n}=55)\end{array}$ & $\begin{array}{c}\text { Abroad } \\
\text { graduates } \\
(\mathbf{n}=10)\end{array}$ & $\begin{array}{c}\text { SQU } \\
(n=49)\end{array}$ & $\begin{array}{c}\text { OMC } \\
(n=55)\end{array}$ & $\begin{array}{c}\text { Abroad } \\
\text { graduates } \\
(\mathbf{n}=10)\end{array}$ \\
\hline $\begin{array}{l}\text { Rotation through OBGYN } \\
\text { during medical school. }\end{array}$ & $\begin{array}{c}26 \\
(53.1)\end{array}$ & $\begin{array}{c}44 \\
(80)\end{array}$ & $\begin{array}{c}8 \\
(80)\end{array}$ & $\begin{array}{c}20 \\
(40.8)\end{array}$ & $\begin{array}{c}9 \\
(16.4)\end{array}$ & $\begin{array}{c}2 \\
(20)\end{array}$ & $\begin{array}{c}3 \\
(6.1)\end{array}$ & $\begin{array}{c}2 \\
(3.6)\end{array}$ & $\begin{array}{c}0 \\
(0)\end{array}$ \\
\hline $\begin{array}{l}\text { Presence of a role model in } \\
\text { OBGYN speciality }\end{array}$ & $\begin{array}{c}26 \\
(53.1)\end{array}$ & $\begin{array}{c}36 \\
(65.5)\end{array}$ & $\begin{array}{c}5 \\
(50)\end{array}$ & $\begin{array}{c}5 \\
(10.2)\end{array}$ & $\begin{array}{c}8 \\
(14.5)\end{array}$ & $\begin{array}{c}1 \\
(10)\end{array}$ & $\begin{array}{c}18 \\
(36.7)\end{array}$ & $\begin{array}{l}11 \\
(20)\end{array}$ & $\begin{array}{c}4 \\
(40)\end{array}$ \\
\hline Faculty interaction & $\begin{array}{c}11 \\
(22.4)\end{array}$ & $\begin{array}{c}27 \\
(49.1)\end{array}$ & $\begin{array}{c}5 \\
(50)\end{array}$ & $\begin{array}{c}36 \\
(73.5)\end{array}$ & $\begin{array}{c}21 \\
(38.2)\end{array}$ & $\begin{array}{c}3 \\
(30)\end{array}$ & $\begin{array}{c}2 \\
(4.1)\end{array}$ & $\begin{array}{c}7 \\
(12.7)\end{array}$ & $\begin{array}{c}2 \\
(20)\end{array}$ \\
\hline $\begin{array}{l}\text { Taking care of a healthy } \\
\text { population }\end{array}$ & $\begin{array}{c}39 \\
(79.6)\end{array}$ & $\begin{array}{c}39 \\
(70.9)\end{array}$ & $\begin{array}{c}9 \\
(90)\end{array}$ & $\begin{array}{c}4 \\
(8.2)\end{array}$ & $\begin{array}{c}5 \\
(9.1)\end{array}$ & $\begin{array}{c}1 \\
(10)\end{array}$ & $\begin{array}{c}6 \\
(12.2)\end{array}$ & $\begin{array}{c}11 \\
(20)\end{array}$ & $\begin{array}{c}0 \\
(0)\end{array}$ \\
\hline $\begin{array}{l}\text { Patient desire for a female } \\
\text { physician }\end{array}$ & $\begin{array}{c}41 \\
(83.7)\end{array}$ & $\begin{array}{c}49 \\
(89.1)\end{array}$ & $\begin{array}{c}6 \\
(60)\end{array}$ & $\begin{array}{c}1 \\
(2)\end{array}$ & $\begin{array}{c}2 \\
(3.6)\end{array}$ & $\begin{array}{c}1 \\
(10)\end{array}$ & $\begin{array}{c}7 \\
(14.3)\end{array}$ & $\begin{array}{c}4 \\
(7.3)\end{array}$ & $\begin{array}{c}3 \\
(30)\end{array}$ \\
\hline Cultural expectations & $\begin{array}{c}30 \\
(59.2)\end{array}$ & $44(80)$ & $\begin{array}{c}5 \\
(50)\end{array}$ & $\begin{array}{c}3 \\
(6.1)\end{array}$ & $\begin{array}{c}1 \\
(1.8)\end{array}$ & $\begin{array}{c}1 \\
(10)\end{array}$ & $\begin{array}{c}17 \\
(34.7)\end{array}$ & $\begin{array}{c}9 \\
(16.4)\end{array}$ & $\begin{array}{c}4 \\
(40)\end{array}$ \\
\hline Surgical opportunities & $\begin{array}{c}24 \\
(49)\end{array}$ & $\begin{array}{c}30 \\
(54.5)\end{array}$ & $\begin{array}{c}8 \\
(80)\end{array}$ & $\begin{array}{c}20 \\
(40.8)\end{array}$ & $\begin{array}{c}19 \\
(34.5)\end{array}$ & $\begin{array}{c}2 \\
(20)\end{array}$ & $\begin{array}{c}5 \\
(10.2)\end{array}$ & $\begin{array}{c}6 \\
(10.9)\end{array}$ & $\begin{array}{c}0 \\
(0)\end{array}$ \\
\hline Time demands & $\begin{array}{c}5 \\
(10.2)\end{array}$ & $\begin{array}{c}6 \\
(10.9)\end{array}$ & $\begin{array}{c}1 \\
(10)\end{array}$ & $\begin{array}{c}36 \\
(73.5)\end{array}$ & $\begin{array}{c}47 \\
(85.5)\end{array}$ & $\begin{array}{c}6 \\
(60)\end{array}$ & $\begin{array}{c}8 \\
(16.3)\end{array}$ & $\begin{array}{c}2 \\
(3.6)\end{array}$ & $\begin{array}{c}3 \\
(30)\end{array}$ \\
\hline Levels of stress & $\begin{array}{c}2 \\
(4.1)\end{array}$ & $\begin{array}{c}3 \\
(5.5)\end{array}$ & $\begin{array}{c}1 \\
(10)\end{array}$ & $\begin{array}{c}45 \\
(91.8)\end{array}$ & $\begin{array}{c}43 \\
(78.2)\end{array}$ & $\begin{array}{c}6 \\
(60)\end{array}$ & $\begin{array}{c}2 \\
(4.1)\end{array}$ & $\begin{array}{c}9 \\
(16.4)\end{array}$ & $\begin{array}{c}3 \\
(30)\end{array}$ \\
\hline Night duties & $\begin{array}{c}3 \\
(6.1)\end{array}$ & $\begin{array}{c}2 \\
(3.6)\end{array}$ & $\begin{array}{c}0 \\
(0)\end{array}$ & $\begin{array}{c}35 \\
(71.4)\end{array}$ & $\begin{array}{c}41 \\
(74.5)\end{array}$ & $\begin{array}{c}6 \\
(60)\end{array}$ & $\begin{array}{c}11 \\
(22.4)\end{array}$ & $\begin{array}{c}12 \\
(21.8)\end{array}$ & $\begin{array}{c}4 \\
(40)\end{array}$ \\
\hline $\begin{array}{l}\text { Income prospects/financial } \\
\text { opportunities }\end{array}$ & $\begin{array}{c}20 \\
(40.8)\end{array}$ & $\begin{array}{c}32 \\
(58.2)\end{array}$ & $\begin{array}{c}6 \\
(60)\end{array}$ & $\begin{array}{c}7 \\
(14.3)\end{array}$ & $7(12.7)$ & $\begin{array}{c}1 \\
(10)\end{array}$ & $\begin{array}{c}22 \\
(44.9)\end{array}$ & $\begin{array}{c}16 \\
(29.1)\end{array}$ & $\begin{array}{c}3 \\
(30)\end{array}$ \\
\hline Spouse/family opinion & $\begin{array}{c}19 \\
(38.8)\end{array}$ & $\begin{array}{c}26 \\
(47.3)\end{array}$ & $\begin{array}{c}4 \\
(40)\end{array}$ & $\begin{array}{c}10 \\
(20.4)\end{array}$ & $\begin{array}{c}15 \\
(27.3)\end{array}$ & $\begin{array}{c}2 \\
(20)\end{array}$ & $\begin{array}{c}20 \\
(40.8)\end{array}$ & $\begin{array}{c}14 \\
(25.5)\end{array}$ & $\begin{array}{c}4 \\
(40)\end{array}$ \\
\hline $\begin{array}{l}\text { Affect family life/family } \\
\text { considerations }\end{array}$ & $\begin{array}{c}1 \\
(2)\end{array}$ & $\begin{array}{c}4 \\
(7.3)\end{array}$ & $\begin{array}{c}0 \\
(0)\end{array}$ & $\begin{array}{c}33 \\
(67.3)\end{array}$ & $\begin{array}{c}39 \\
(70.9)\end{array}$ & $\begin{array}{c}4 \\
(40)\end{array}$ & $\begin{array}{c}15 \\
(30.6)\end{array}$ & $\begin{array}{c}12 \\
(21.8)\end{array}$ & $\begin{array}{c}6 \\
(60)\end{array}$ \\
\hline
\end{tabular}

$S Q U=$ Sultan Qaboos University; OMC = Oman Medical College; OBGYN = obstetrics and gynaecology.

cular strategies have been suggested by other countries to increase the intake of residents in OBGYN, yet it appears that recognising the students at the entry level in their clerkship years and having residents who act as role models would help to motivate students. ${ }^{4}$

During their internship training, medical graduates in Oman undergo mandatory rotations in internal medicine and general surgery and the third rotation is a choice of either paediatrics or OBGYN. This varies the exposure to OBGYN, especially since most graduates choose paediatrics rather than OBGYN during their internship year. Hammoud et al. reported that an OBGYN clerkship in the third year of their curriculum (which may be sixth or seventh year for SQU students) was the strongest predictor of interest in the speciality. ${ }^{8}$ As a future direction we believe additional exposure during internship may increase interest in the OBGYN speciality, for female graduates in particular.

In exploring the role of gender in the OBGYN speciality, Balayla concluded that male gynaecologists 
can provide high-quality care for females, yet culture is still the most discouraging factor for males in choosing this speciality in Oman. ${ }^{9}$ Chang et al. reported that male students experienced gender bias and described feeling socially excluded from clinical teams dominated by females. ${ }^{10}$ To correct this, Craig et al. suggested that male students have early exposure to OBGYN in the pre-clinical years and encouraged the medical faculty to ensure that all students have a positive experience during their clerkship. ${ }^{11}$ A review by Lyon also commented on females' dominance in the speciality and expressed fear regarding the security of the speciality. ${ }^{12}$

Efforts need to be made to increase awareness about this issue and to encourage male graduates to join the OBGYN speciality. Raising awareness can start with OBGYN training during the clinical years of medical school and throughout. When a gynaecologist is needed, it should not matter whether the doctor is a male or female (as happens in Saudi Arabia and many other Muslim and Arab countries). Television and radio awareness programmes could play a major role in enlightening the population. Announcements by muftis on this issue would also be helpful. Nevertheless, in view of the cultural preference for female gynaecologists, increasing the number of female medical graduates choosing this speciality needs to be a priority.

The results of this study are limited due to the nonhomologous nature of the sample (interns and postintern doctors), the participants' recent postings at the time of survey and the unequal sample size from different institutions. Another factor was the limited number of participating males; however, approximately $66 \%$ of students at SQU are female even among the undergraduates. Hence, the male response rate of $22 \%$ is acceptable in that it reflects the current situation.

\section{Conclusion}

Female and male students need more exposure to the OBGYN speciality earlier in their training. OBGYN should be made a mandatory rotation in the internship programme, especially for females. Reducing workrelated stress, offering more incentives and ensuring the presence of role models in the speciality will help persuade more interns to choose this speciality. Religious leaders and the media should help in educating the public and encourage more students to choose this speciality.

\section{CONFLICT OF INTEREST}

The authors declare no conflicts of interest.

\section{FUNDING}

No funding was received for this study.

\section{References}

1. Bédard MJ, Berthiaume S, Beaulieu MD, Leclerc C. Factors influencing the decision to practise obstetrics among Québec medical students: A survey. J Obstet Gynaecol Can 2006; 28:1075-82. https://doi.org/10.1016/S1701-2163(16)32323-4.

2. Abu-Rafea BF, Al-Hassan BF, Al Nakshabandi KA, Rahbini NO, Al-Shaikh GK. Factors influencing students' decision in choosing obstetrics and gynecology as a career in a university hospital in central Saudi Arabia. Saudi Med J 2011; 32:730-4.

3. Scott IM, Nasmith T, Gowans MC, Wright BJ, Brenneis FR. Obstetrics and gynaecology as a career choice: A cohort study of Canadian medical students. J Obstet Gynaecol Can 2010; 32:1063-9. https://doi.org/10.1016/S1701-2163(16)34715-6.

4. Chang JC, Odrobina MR, McIntyre-Seltman K. Residents as role models: The effect of the obstetrics and gynecology clerkship on medical students' career interest. J Grad Med Educ 2010; 2:341-5. https://doi.org/10.4300/JGME-D-09-00070.1.

5. Fogarty CA, Bonebrake RG, Fleming AD, Haynatzki G. Obstetrics and gynecology--to be or not to be? Factors influencing one's decision. Am J Obstet Gynecol 2003; 189:652-4. https://doi.org/10. 1067/S0002-9378(03)00880-9.

6. Times of Oman. 'More than 88,000 live births reported in Oman last year'. From: https://timesofoman.com/article/119474 Accessed: Nov 2018.

7. Ogburn T, Espey E, Autry A, Leeman L, Bachofer S. Why obstetrics/gynecology, and what if it were not an option? A survey of resident applicants. Am J Obstet Gynecol 2007; 197:538.e1-4. https://doi.org/10.1016/j.ajog.2007.07.024.

8. Hammoud MM, Stansfield RB, Katz NT, Dugoff L, McCarthy J, White CB. The effect of the obstetrics and gynecology clerkship on students' interest in a career in obstetrics and gynecology. Am J Obstet Gynecol 2006; 195:1422-6. https://doi.org/10.1016/j. ajog.2006.07.044

9. Balayla J. Male physicians treating female patients: Issues, controversies and gynecology. Mcgill J Med 2011; 13:72.

10. Chang JC, Odrobina MR, McIntyre-Seltman K. The effect of student gender on the obstetrics and gynecology clerkship experience. J Womens Health (Larchmt) 2010; 19:87-92. https://doi.org/10.10 89/jwh.2009.1357.

11. Craig LB, Buery-Joyner SD, Bliss S, Everett EN, Forstein DA, Graziano SC, et al. To the point: Gender differences in the obstetrics and gynecology clerkship. Am J Obstet Gynecol 2018; 219:430-5. https://doi.org/10.1016/j.ajog.2018.05.020.

12. Lyon DS. Graduate education in women's health care: Where have all the young men gone? Curr Womens Health Rep 2002; 2:170-4. 